\title{
Effectiveness of Work Life Balance (WLB) on Job Satisfaction of Employees working in Banks
}

\section{R. Dinakar}

\begin{abstract}
The passage of new private banks improves operational effectiveness and intensity in the Indian financial system. The new private area banks have presented state-of-theart and inventive administrations and products to catch the high market share of the overall banking industry. This progression the working example of the employees in the financial sector. The findings of the study shows that equilibrium work life balance, responsibility, Institutional help, and monetary help are determinants of the $W L B$ of representatives in new private area banks. The outcomes demonstrate that there is a critical distinction between the financial status of employees and determinants of $W L B$ in new private area banks. The outcomes likewise suggest that WLB, Organizational help, monetary help, and responsibility are fundamentally and emphatically affecting the work fulfillment of representatives in new private area banks. The new private area banks should offer work-family uphold programs in particular youngster care uphold and adaptable working timings to diminish employee pressure and encourage to the administration of family and work viably. Moreover, new private banks should actualize arrangements of anticipation of lewd behavior, yearly health checkups, and sick leaves successfully so that employees can satisfy with their roles and in turn increase the productiveness of their operations.
\end{abstract}

Key Words: Work Life Balance, Job Satisfaction, Operational Effectiveness, Private Banks, Employees.

\section{INTRODUCTION}

These days WLB is a significant issue for both employees and managers by and large in the service industry and especially in the financial sector, where workers are overburden with work and simultaneously, they need to adjust their day-to-day life (Goyal and Babel, 2015). WLB is the people fulfilled in, for example, the manner in which they divide their energy and time among work and individual and day to day life. The employees who are happy with their harmony between serious and fun times are invigorated, eager, and focused on their work. Advancement and privatization measures initiate the Indian financial area to embrace change procedures and battle for a serious edge over their rivals in an exceptionally changed and dynamic financial business. The passage of new private area banks improves operational proficiency and intensity in the Indian financial industry. The new private area banks have presented new and inventive administrations and items to catch the high piece of the overall industry.

Manuscript received on March 08, 2021.

Revised Manuscript received on March 12, 2021.

Manuscript published on March 30, 2021.

* Correspondence Author

R. Dinakar, Research Scholar, Department of Business Management, Osmania University, Hyderabad. Email ID: r.dinakar999@gmail.com

(C) The Authors. Published by Blue Eyes Intelligence Engineering and Sciences Publication (BEIESP). This is an open access article under the CC BY-NC-ND license (http://creativecommons.org/licenses/by-nc-nd/4.0/)
This progression the working example of the employees in the financial area (Seth, 2014). Overseeing WLB is a vital assignment for employees that help to lead a daily existence solid and stable. Better harmony between serious and fun times encourages in fixing needs by ladies, comprehension of existing workplace and position, refreshing their insight and abilities, fixing time plan for family, and assessing execution. Great harmony between serious and fun times isn't just aiding workers at the same time, likewise family and banks. Subsequently, the current research is endeavored to consider WLB and occupation fulfillment of employees working in private area banks.

\section{REVIEW OF LITERATURE}

Clopping's (2020) commitment, in current occasions, the human asset office's significant accentuation is to keep a harmony among expert and individual life. He found that because of the consolidation of expert existence with individual life, positive and negative effects are related.

Chick (2019), employees need fixation due to the individual obligations and obligations. Also, in the individual life, they are stressed over their work obligations and thus, neither one of the they can make the most of their own life nor can have greatness in their expert life. Thus, keeping up the equilibrium is a serious need. For the extent of the proposition, the equilibrium between fun and serious stuff can be characterized as a harmony among expert and individual life. The harmony between serious and fun times can be characterized as a connection between paid work and individuals' lives outside of their business, and the balance between these two can be acquired, in light of individual requirements, assumptions, and yearnings of an individual, harmony between serious and fun times can be influenced by work power, low maintenance work, expanded positions in help areas.

Lee-Ross and Pryce (2018) WLB ends up being a need for individual fulfillment. As now ladies are additionally in the corporate world so a harmony between serious and fun times has commanded much more notice. This is so in light of the fact that, for ladies, it's very troublesome and significant that they need to adjust both their expert and individual life... The impacts of equilibrium between fun and serious stuff can be unique, and they might be diverse for the two people. With the increment in the quantity of expert working hours or the expansion in friendly exercises, equilibrium between fun and serious stuff is influenced.

Helmond (2017), Due to the issues and stress in close to home life, representatives have been adversely influenced which additionally influences authoritative execution.

Published By:

Blue Eyes Intelligence Engineering \& Sciences Publication

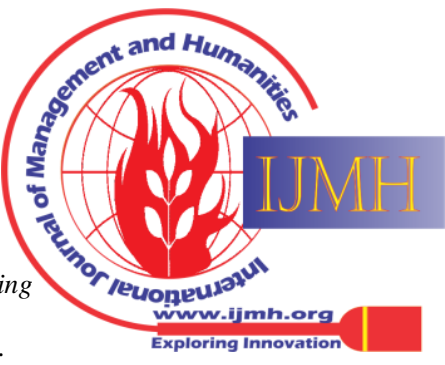


He expressed that the association of the representatives with their families during the working hours breaks or intrudes on the association of workers with their work obligations. Representatives' correspondence with loved ones during office working hours at times causes genuine strains and stress in the worker.

It lessens the effectiveness and focus level of the workers and they do not have the feeling of inspiration to perform well in the association.

Holt et. al, (2016) Subsequently, the degree of execution is now and again less than ideal. There can likewise be situations where the representatives are approached to work for longer hours, so in those cases, the significance of equilibrium between fun and serious stuff is much more featured. For the present circumstance on account of banks, the banks offer worthwhile advantages to the workers, and the representatives might need to get these advantages with the end goal of their advancements in positions and award. Those representatives who work longer hours are viewed as capable and devoted paying little heed to the advantage acquired by the association in association with their long working hours. Consequently, and the motivators offered to the representatives, they try to work for longer hours to such an extent that they can be considered for the advancement and for the expanded prize for their administrations to the banks. In light of the expanded working hours, the presentation of the individual may lessen, and the individual will be unable to perform successfully for the additional time when contrasted with the standard time. Equilibrium suggests the idea of value and sensibility, the obsessive workers work for longer hours, which is considered as misbalanced work life due to the absence of acknowledgment of the standards about where and how long and energy is to be spent, in proficient life bringing about clashes between the expert and individual life.

Clutterbuck, (2015). For the harmony between serious and fun times, an individual is needed to consider the sensibility of the time consumed for his social time on earth and individual life, and for this reason, the overall insight acknowledged in the social and expert bodies for working hours are to be considered as the standard for differentiating the normal and uncommon working hours. The excellent longer working hours may influence the equilibrium between fun and serious stuff if the social necessities of an individual are very requesting, notwithstanding, if an individual isn't so friendly and needn't bother with much an ideal opportunity for their own life may have less issues.

Richenda Gambles, Suzan Lewis, Rhona (2014), these days the representatives are giving 24 hours administration any place they are simply to satisfy the work prerequisites and obligations and consequently, they are been remunerated different motivations. On one side, these offices have helped workers in profiting motivating forces, benefits, and rewards through which they are meeting distinctive monetary necessities and needs.

Fleche (2013) states that these offices have upset the everyday existence of representatives adversely. One is that just to get these monetary prizes, the individual existences of the workers are upset as they don't invest a large part of the energy with their families. Consequently, Family life has been discovered to be truly influenced by the consolidation and covering of work and public activity.

Julie Cohen (2012), representatives are working for the associations even in their off timings and occasions. This is no uncertainty being compensated by the association too, which eventually helps workers, however there is no substitution for joy and fulfillment that one gets from their family. Likewise, public activity additionally requires the liberation of legitimate planning and consideration for keeping up solid connections. Prior to the headway of innovation and the improvement of various gadgets by specialists, life was one moment and associated with each update.

Soreen Dressier (2011), with the progression of time, innovation created various methods for collaboration and correspondence beginning from a straightforward home phone, which further changed into pocket mobiles.

Anna, Teppo Kroger, Pohjola (2010) gadgets assisted individuals to stay in contact with one another for the duration of the day. On one side it ends up being a gift to beat the correspondence boundaries however on the opposite side, it has associated the individual in managing such countless matters while keeping up balance has troublesome. Workers are approached to stay in contact with the association to tackle the issue or question when required and to address the association's issues. On the opposite side, families need to stay in correspondence with the individual at work so they can likewise look for help during the hour of need.

Hill (2009) contributed that every life is significant from its own measurements and point of view and now they are found to cover one another. Now and then, work-life of an individual rules the individual existence of an individual, which results from the enduring of the relations of the person. Essentially, when the individual life becomes ruling, the expert execution of the representative is adversely influenced which ends up being an issue for the administration. Taking everything into account, neither one of the lives ought not be coordinated toward anguish and obliviousness nor ought to be focused on over the other one. The versatile can make an individual accessible at the work environment every one of the occasions, and comparatively, an individual is accessible for social association constantly.

Weinberg \& Cooper, (2008) The effects at the work environment of social mediation with the expert obligations and duties are negative as a result of the redirected consideration. Individuals are associated with one another and with the exercises which are not ideal during the working hours through cell phones. The answer for this issue can be the restricted utilization of mobiles for nonpertinent purposes at lower chain of importance staff, for example, the staff on the front counter may not be permitted to utilize a cell phone, while the staff, for example, an individual reacting to the advance assistance delegate, and another division, for example, help in coordination office to answer the questions on telephone. The utilization of cell phones isn't anyway limited for administrative staff and the controls for them are adaptable for the communication that they can make on telephones and different mediums. The usage of web channels can impede undesirable sites at the working environment like the sites for social correspondences.

Published By:

Blue Eyes Intelligence Engineering \& Sciences Publication

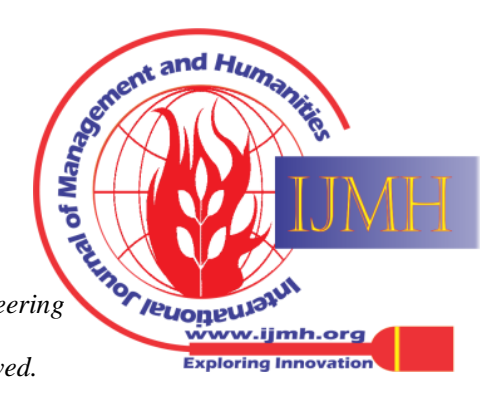


Associations have different objectives and targets which are achieved through workers' proficiency and viability in the given time span. Nonetheless, when associations can't produce the results in the accessible time, representatives are expected to work in their off timings as well. On the opposite side, representatives stay in contact with their families during office time and they have correspondence with them during office work, which keeps their consideration redirected to various things.

Lockett, (2007). This eventually causes significant issues for the administration of the association to keep its representatives zeroed in on their work and meet the objectives.

H.L. Kaila (2006), when the individual life is associated with the expert life, now and again it brings uplifting news, which decidedly affects the presentation of the representative while some get awful news from the public activity, at that point it makes forcefulness, stress, strain, and enduring in the workers which turns into an issue for the association differently. For an individual, both the social and the expert life should be similarly imperative to get fulfilled.

\section{METHODOLOGY}

The information is gathered from 300 employees of private area banks by utilizing an irregular testing strategy through an organized poll. The recurrence and rate investigation are completed to know the financial status of workers of new private area banks. Exploratory factor examination is accomplished for recognizing the determinants of WLB of representatives in new private area banks. The ANOVA test is done to consider the contrast between the financial status of representatives and determinants of harmony between serious and fun times in new private area banks. Multiple regression analysis is utilized to examine the impact of determinants of equilibrium between fun and serious stuff on work fulfillment of employees in new private area banks.

\section{RESULTS AND DISCUSSION}

This study is directed by focusing on employees working in various banks to secure the data that can help in the results and discoveries from the outcome. When utilizing the Reliability tests with SPSS on all factors the Cronbach alpha was .87, which implies a significant consistency in the example as demonstrated in the accompanying table.

Table-4.1: Reliability Statistics

\begin{tabular}{|l|l|}
\hline Cronbach Alpha & Number of Employees \\
\hline .84 & 300 \\
\hline
\end{tabular}

Table-4.2: Socio Economic Status of Employees

\begin{tabular}{|c|c|c|}
\hline Age Group & No. of Employees & $\%$ \\
\hline $20-29$ Years & 180 & $60 \%$ \\
\hline $30-39$ Years & 60 & $20 \%$ \\
\hline $40-49$ Years & 45 & $15 \%$ \\
\hline Above 50 Years & 15 & $5 \%$ \\
\hline
\end{tabular}

Table-4.2 (a): Educational Qualifications of Employees

\begin{tabular}{|l|l|l|}
\hline Secondary School & 120 & $40 \%$ \\
\hline Pre-University & 30 & $10 \%$ \\
\hline Under graduation & 90 & $30 \%$ \\
\hline Post-graduation & 45 & $15 \%$ \\
\hline Doctoral degree & 15 & $5 \%$ \\
\hline
\end{tabular}

Table-4.2 (b): Designation of Employees \begin{tabular}{|l|l|l|}
\hline Clerical Staff & 225 & $75 \%$ \\
\hline
\end{tabular}

\begin{tabular}{|l|l|l|}
\hline Probationary Officers & 66 & $12 \%$ \\
\hline Managers & 9 & $3 \%$ \\
\hline
\end{tabular}

Table-4.2 (c): Average Monthly Income of Employees

\begin{tabular}{|c|c|c|}
\hline Less than 20000/- & 195 & $65 \%$ \\
\hline Between 20000/-- 50000/- & 93 & $31 \%$ \\
\hline Above 50000/- & 12 & $4 \%$ \\
\hline
\end{tabular}

Table-4.2 (d): Average work experience of Employees

\begin{tabular}{|c|c|c|}
\hline Less than 5 Years & 189 & $63 \%$ \\
\hline Between $5-10$ Years & 93 & $31 \%$ \\
\hline Above 10 Years & 18 & $6 \%$ \\
\hline
\end{tabular}

Determinants of WLB in private banks: To distinguish the determinants of WLB of workers in private banks, exploratory factor examination is done and the outcomes are as per the following. The aftereffects of the Kaiser-MeyerOlkin (KMO test) proportion of examining ampleness $(\mathrm{KMO}=.759)$ and Bartlett's Test of Sphericity (Chi-square worth $=.0031$ ) demonstrate that the factor investigation strategy is fitting. Four factors that are separated that represent a sum of 71.79 percent of minor departure from nineteen factors. Every one of the four elements adds to 24.13 percent, 18.69 percent, 16.73 percent, and 12.29 percent individually.

Factor-I: Incorporates WLB strategy is been set up advertisement all around characterized, workers are told to follow and acknowledge the WLB strategy, banks give WLB strategy that encourages representatives to meet their family commitments, banks organize explicit projects for representatives to look after WLB, banks offer preparing to workers for WLB, usage of WLB approaches make representatives' work simple and representatives mindful of WLB strategies of their banks. Consequently, this factor is named as WLB.

Factor-II: Contains employees work responsibility builds their responsibility, workers are prepared to take more errands at a going full bore, the work gets workers far from their family, the usage of novel thoughts make work pressing factor and workers need to accomplish beyond what they can bargain serenely. Consequently, this factor is named Work Load.

Factor-III: Comprises of banks give help to representatives to manage family and business-related issues, banks focus on prosperity of workers, banks uphold workers for adjusting family and expert life and representatives offer significance to their dire family issues. Along these lines, this factor is named as Hierarchical Support.

Factor-IV: manages banks give better remuneration to their representatives, banks give monetary help to their workers for resource creation and banks give agreeable reimbursement timetables to credits to their workers. Thus, this factor is named Financial Support.

Cronbach's Alpha worth is .84 showing that each measure displays a satisfactory degree of inward consistency. It uncovers that equilibrium between fun and serious stuff arrangements, responsibility, authoritative help, and monetary help are determinants of the WLB of representatives in private banks. Financial status of representatives and determinants of WLB in private banks:

Blue Eyes Intelligence Engineering \& Sciences Publication

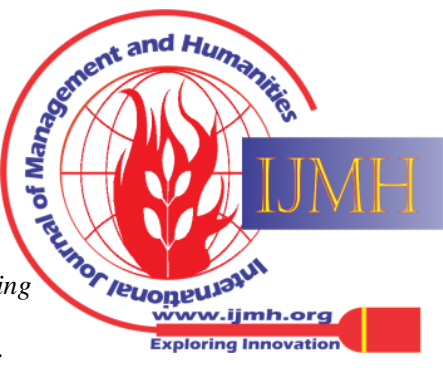


To consider the contrast between the financial status of representatives and determinants of WLB in private banks,

the ANOVA test is done and the outcomes are appeared in Table 3.

Table-3: Difference between Socio-economic Status and determinants of WLB

\begin{tabular}{|l|l|}
\hline \multicolumn{1}{|c|}{ Determinants } & Value of F \\
\hline Age of Employees and Determinants of WLB & 23.456 \\
\hline Educational Qualifications of Employees and Determinants of WLB & 19.342 \\
\hline Designation of employees and Determinants of WLB & 16.013 \\
\hline Average Monthly Income and Determinants of WLB & 13.241 \\
\hline Average Work Experience and Determinants of WLB & 15.671 \\
\hline
\end{tabular}

* Level of Significance (LOS=0.001)

From the table- 3 it is by implied that the results obtained at $0.001 \%$ of Los are significant and it indicates the significant difference between determinants of WLB and Socioeconomic status of employees working in private sector banks. A Normality Test is conducted to check the data obtained were normal or not? And also, whether the data is distributed normally or not.

Table-4: Normality Test Results

\begin{tabular}{|l|l|l|}
\hline Particulars & Mean & SD \\
\hline WLB & 3.69 & .41 \\
\hline Effectiveness of Operations & 3.81 & .39 \\
\hline
\end{tabular}

Effectiveness of determinants of WLB on work fulfillment of representatives in private banks: To break down the impact of determinants of WLB on work fulfillment of workers in new private area banks, the Multiple $\mathrm{R}$ analysis are introduced in Table 5 . The coefficient of Multiple R is 0.71 and the adjusted $\mathrm{R}$ value is 0.69 . It is derived that about 61.00 percent of the variety in the needy variable (Job Satisfaction) is clarified by the free factors. The F Value 29.741 is genuinely huge at a one percent level showing that the model is huge.

Table-5: Effectiveness of Determinants of WLB on Job Satisfaction of in Private Banks

\begin{tabular}{|l|c|}
\hline \multicolumn{1}{|c|}{ Determinants of WLB } & Multiple R \\
\hline WLB Strategies - Factor-I & .465 \\
\hline Work Load - Factor-II & .341 \\
\hline Hierarchical Support - Factor-II & .417 \\
\hline Financial Support - Factor-IV & .387 \\
\hline${ }_{\mathrm{R}} 2$ & 0.71 \\
\hline Adjusted R & 0.69 \\
\hline F & 29.741 \\
\hline
\end{tabular}

* Level of Significance (LOS=0.001)

The outcomes uncover that WLB strategies, hierarchical help, monetary help, and workload are altogether and decidedly impacting the work fulfillment of representatives in private banks at one percent level.

\section{CONCLUSION}

The results shows that WLB strategies, workload, hierarchical help and monetary help are determinants of work life balance of employees in private banks. The outcomes show that there is critical distinction between financial status of representatives and determinants of WLB in private banks. The outcomes additionally suggest that WLB, hierarchical help, monetary help and responsibility are fundamentally and decidedly impacting the work fulfillment of representatives in private banks. The private banks should offer work-family uphold programs in particular child care uphold and flexi working timings to lessen worker's pressure and encourage to oversee family and work successfully. Moreover, private banks should actualize arrangements of avoidance of inappropriate behavior, annual health checkups and sick leave adequately. Plus, the private banks should lead WLB and family guiding projects routinely for their workers. Additionally, the private banks ought to energize conversations with their representatives through web-based media to comprehend and meet their WLB and needs.

\section{REFERENCES}

1. Anita, K. and Uma Maheshwari, (2014), "Work Life Balance among Women Bankers - A Conceptual, Theoretical and Literature Framework", Global Journal for Research Analysis, 3(12): pp.126128.

2. Dev, G.N., (2012), "Employees' Perception on Work Life Balance and Its Relation with Job Satisfaction in Indian Public Sector Banks", International Journal of Exclusive Management Research, 2(2): pp.113.

3. Emmanuel, R. and Alluri Balaji, (2014), "Work-life Balance of Women in Banks-A Factor Analysis", International Journal of Marketing \& Financial Management, 2(1): pp.25-40.

4. Goyal, K. A. and Arpita Agrawal Babel, (2015), "Issues and Challenges of Work Life Balance in Banking Industry of India", Pacific Business Review International, 8(5): pp.113-118.

5. Lalita Kumari, (2012), "Employees' Perception on Work Life Balance and It's Relation with Job Satisfaction in Indian Public Sector Banks", Indian Journal of Economics and Management Research, 2(2). pp.113.

6. Mary Julia Sabarmati and Rajani Babu, R., (2015), "Human Resource Management Practices in Selected Private Sector Banks in Pondicherry - A Special Reference to Work Life Balance of Women Employees", International Journal of Advanced Scientific Research \& Development (IJASRD), pp.104-110.

7. Upasana Joshi Seth, (2014), "Influence of Work Life Balance on Organizational Commitment: A Comparative Study of Women Employees Working in Public and Private Sector Banks", European Journal of Business and Management, 6(34): pp.215-219. 
8. Baridhara, V. and Vasanth, S., (2012), "Work Life Balances A Source of Job Satisfaction - An Exploratory Study on the View of Women Employees in the Service Sector", International Journal of Multidisciplinary Research, 2(3): pp.450-458.

9. Vijaya, T.G. and Hema Malini, R., (2012), "Impact of Work Life Balance on Organizational Commitment among Bank Employees", Asian Journal of Research in Social Science \& Humanities, 2: pp.159171.

10. Vijayalakshmi, P.S. and Amusia, M., (2015), "A Study on Quality of Work Life among Employees of Public Sector Banks in Tiruchirappalli District”, Journal of Exclusive Management Science, 4(3): pp.1-12.

\section{AUTHOR(S) PROFILE}

R. Dinakar, Research Scholar Department of Business Management, Osmania University, Hyderabad.

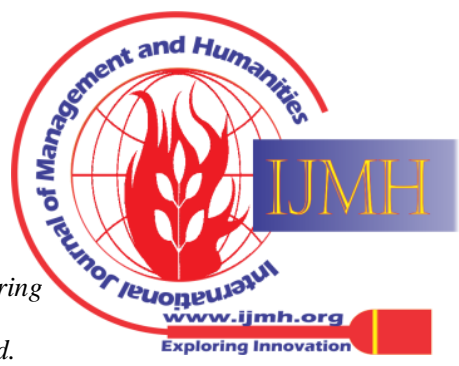

